\title{
Pregnancy and Childbirth: An Unexpected Cakewalk for a Mother With Beta Thalassemia Major Homozygous for IVS (G-C) Mutation
}

\author{
Mousumi D. Ghosh ${ }^{1}$, Mamta R. Datta ${ }^{1}$, Vinita Singh ${ }^{1}$, Farah Rana ${ }^{2}$ \\ 1. Department of Obstetrics and Gynaecology, Tata Main Hospital, Jamshedpur, IND 2. Department of Pathology, Tata \\ Main Hospital, Jamshedpur, IND
}

Corresponding author: Mousumi D. Ghosh,dr.mousumi@tatasteel.com

\begin{abstract}
The thalassemias are the most common single-gene disorders of hemoglobin synthesis. The salient features of beta thalassemia major, in which both alleles of the HBB gene are affected, are transfusion dependency and iron overload. Although with advances in treatment, the life expectancy in such patients has increased, they have difficulty in conceiving. We report a case of pregnancy in a beta thalassemia major patient who was transfusion independent and had no iron overload. Genetic analysis revealed IVS 1-5 (G-C) mutation in the homozygous state which usually manifests in severe disease and blood transfusion dependency. On the contrary, she did not need blood transfusion, had a smooth antenatal period and a vaginal delivery at term with a favorable childbirth experience. This case report highlights complex genetic interplay and the role of fetal hemoglobin ( $\mathrm{HbF}$ ) enhancer loci which modulates $\mathrm{HbF}$ levels thereby raising total hemoglobin levels.
\end{abstract}

Categories: Genetics, Obstetrics/Gynecology, Hematology

Keywords: beta thalassemia major, ivs $1-5(\mathrm{~g}-\mathrm{c})$ mutation, pregnancy

\section{Introduction}

Thalassemia is one of the most common inherited genetic disorders. The key feature of beta thalassemia major is blood transfusion and iron overload [1]. Medical advances have led to increased life expectancy in these patients, with consequent increase in reproductive desire. Patients with beta thalassemia major rarely conceive due to hypogonadotropic hypogonadism [2]. With assisted conception, there are few case reports of pregnancy in beta thalassemia major. It is considered a very high-risk pregnancy for both mother and fetus. Among the various mutations, IVS 1-5 (G-C) is the severe form whose homozygosity results in severe disease. We report a case of homozygous IVS 1-5 (G-C) mutation who was not transfusion-dependent, conceived spontaneously, and had an uneventful maternal and fetal outcome.

Review began 03/03/2021 Review ended 03/08/2021 Published 03/13/2021

\section{() Copyright 2021}

Ghosh et al. This is an open access article distributed under the terms of the Creative Commons Attribution License CC-BY 4.0., which permits unrestricted use, distribution, and reproduction in any medium, provided the original author and source are credited.

\section{Case Presentation}

A 24-year-old primigravida attended an antenatal clinic at 14 weeks of pregnancy. She was a known case of beta thalassemia major, diagnosed two years back. Hemoglobin $(\mathrm{Hb})$ electrophoresis showed HbA- 6.1\%, $\mathrm{HbF}-91.7 \%$ and $\mathrm{HbA} 2-2.2 \%$ (Figure 1 ). 


\section{Cureus}

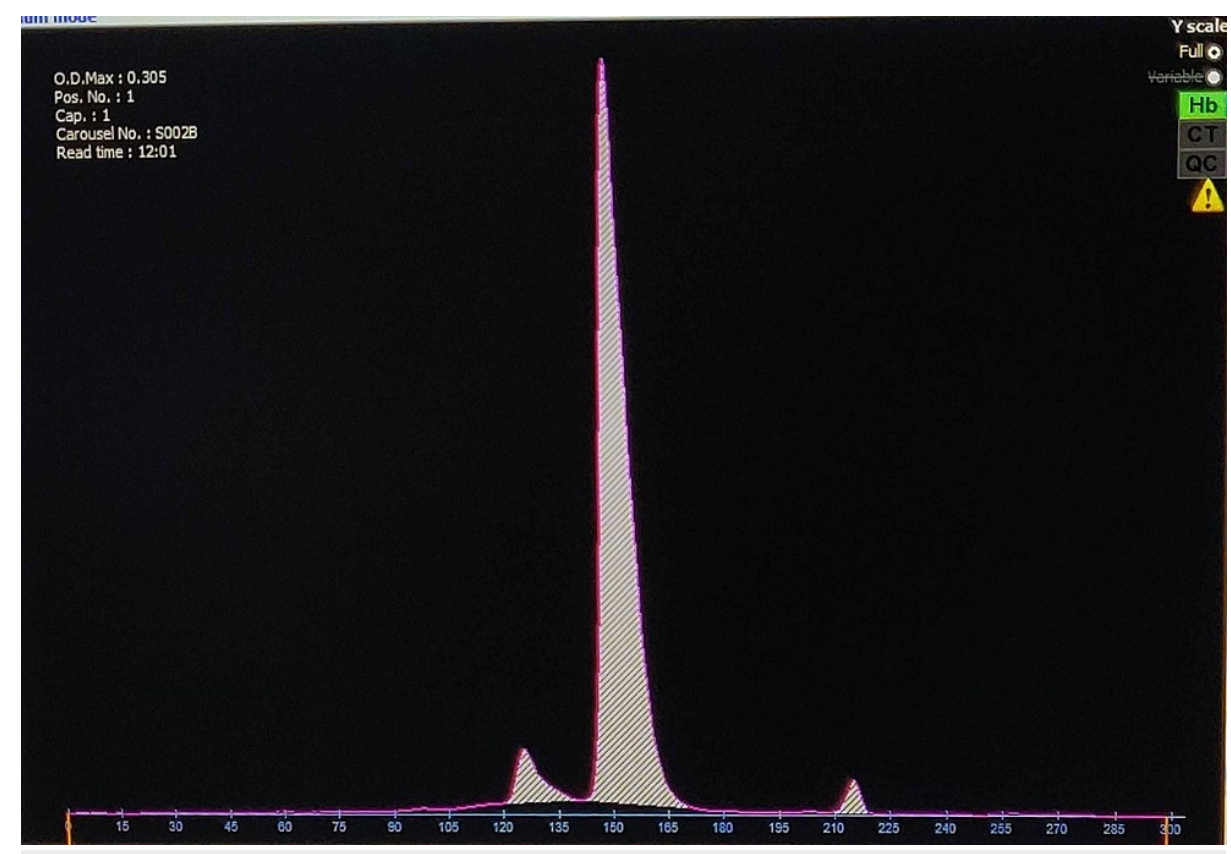

FIGURE 1: Capillary electrophoresis showing $91.7 \% \mathrm{HbF}, 6.1 \% \mathrm{HbA}$, and $2.2 \% \mathrm{HbA} 2$ levels, compatible with a diagnosis of thalassemia major

Her height was 1.57 meters (m), weight 71 kilograms $\left(\mathrm{kg}\right.$ ) and body mass index was $28.8 \mathrm{~kg} / \mathrm{m}^{2}$. She had mild anemia with microcytic hypochromic blood picture. She had no history of blood transfusion and iron chelation therapy. This was a spontaneous conception with no history of infertility. The husband was tested for hemoglobinopathies and was found unaffected, hence the fetus was not subjected to prenatal testing. Her dating scan corresponded to the dates. Anomaly scan at 19 weeks of gestation showed a single live fetus with no anomalies.

Mutational analysis with amplification refractory mutation system polymerase chain reaction (ARMS PCR) using allele-specific primers to screen for beta thalassemia [IVS 1-5 (G-C), CD 41/42 (-CTTT), CD8/9 (+G), CD15 (G-A), CD30 (G-C)], CD6 (A-T) HbS and CD26 (G-A) HbE] was carried out to confirm the hemoglobinopathy. Results showed homozygous for beta thalassemia IVS 1-5 (G-C) mutation. She had regular antenatal check-ups in the outpatient dispensary and had mild anemia. The hematological parameters are described in Table 1. 


\section{Cureus}

\begin{tabular}{|c|c|c|c|}
\hline & 16 weeks & 28 weeks & 38 weeks \\
\hline Hemoglobin & $9.8 \mathrm{~g} / \mathrm{dl}$ & $9.6 \mathrm{~g} / \mathrm{dl}$ & $9.8 \mathrm{~g} / \mathrm{dl}$ \\
\hline Mean corpuscular volume (MCV) & $68.2 \mathrm{fL}$ & & $74.4 \mathrm{fL}$ \\
\hline Mean corpuscular hemoglobin (MCH) & $21.3 \mathrm{pg}$ & & $22.7 \mathrm{pg}$ \\
\hline Mean corpuscular hemoglobin concentration (MCHC) & $31.3 \mathrm{pg}$ & & $29.5 \mathrm{pg}$ \\
\hline Total leucocyte count & $10,500 / u L$ & & $17000 / u L$ \\
\hline Platelet count & $156000 / u L$ & & $173000 / u L$ \\
\hline Total bilirubin & $6.12 \mathrm{mg} / \mathrm{dl}$ & $4.61 \mathrm{mg} / \mathrm{dl}$ & $2.56 \mathrm{mg} / \mathrm{dl}$ \\
\hline Indirect bilirubin & $5.38 \mathrm{mg} / \mathrm{dl}$ & $3.72 \mathrm{mg} / \mathrm{dl}$ & $1.37 \mathrm{mg} / \mathrm{dl}$ \\
\hline ALT/AST/ALP & 13/23.5/65.8 U/L & 14.8/33.7/97.2 U/L & 10/32/183 U/L \\
\hline PT INR & 1.05 & 1.08 & 1.06 \\
\hline Serum Iron & $226 \mathrm{mcg} / \mathrm{dL}$ & $322.4 \mathrm{mcg} / \mathrm{dL}$ & \\
\hline Serum Ferritin & $40 \mathrm{ng} / \mathrm{mL}$ & $49.6 \mathrm{ng} / \mathrm{mL}$ & \\
\hline Vitamin B12 & & & $114 \mathrm{ng} / \mathrm{mL}$ \\
\hline Blood sugar & $97 \mathrm{mg} / \mathrm{dl}$ & $108 \mathrm{mg} / \mathrm{dl}$ & $110 \mathrm{mg} / \mathrm{dl}$ \\
\hline Thyroid stimulating hormone (TSH) & $2.21 \mathrm{microlU} / \mathrm{ml}$ & $3.1 \mathrm{microlU} / \mathrm{ml}$ & $2.4 \mathrm{microlU} / \mathrm{m}$ \\
\hline
\end{tabular}

\section{TABLE 1: Hematological parameters at 16, 28 and 38 weeks of gestation}

ALT- alanine aminotransferase; AST- aspartate aminotransferase; ALP- alkaline phosphatase; PT INR- prothrombin time and international normalized ratio

Ultrasound abdomen showed multiple calculi in gall bladder with hepatosplenomegaly. Serial growth scans were done from 24 weeks of pregnancy which showed normal fetal growth. Her blood pressure and blood sugar levels were in the normal range throughout pregnancy.

She was admitted to the labor room at 39 weeks 4 days of gestation with pain in abdomen and had spontaneous onset of labor. She delivered vaginally with an APGAR (Appearance, Pulse, Grimace, Activity, and Respiration) score of 9/10 and baby weight of $2.7 \mathrm{~kg}$. It was an uneventful delivery with no maternal or fetal morbidity.

\section{Discussion}

Patients with beta thalassemia major are transfusion-dependent and suffer from effects of iron overload. Of the various mutations, homozygosity for beta thalassemia IVS 1-5 (G-C) is the most common mutation in the Indian subcontinent and manifests in severe form. On the contrary, our patient had no history of blood transfusion before pregnancy and did not require one during pregnancy and labor.

These patients have reduced fertility and usually need assistance to conceive. After conception, there are increased risks to both mother and fetus, hence needing multidisciplinary treatment [3,4]. Maternal risks include cardiomyopathy, endocrinopathies (diabetes mellitus, hypothyroidism, hypoparathyroidism), severe maternal anemia, alloimmunization, viral infections, thrombosis and bone disturbances. These patients have iron overload and may need iron chelation in the second and third trimesters of pregnancy. Fetal risks include early pregnancy loss and growth restriction [5].

We report a case of thalassemia major who conceived spontaneously without any history of infertility. Our patient had mild anemia and hemolytic jaundice. The red cell indices mean corpuscular volume (MCV) and mean corpuscular hemoglobin ( $\mathrm{MCH}$ ) were below the cut-off of 80fL and 27pg with a high red cell distribution and normal red cell count. Her serum iron and ferritin levels were within range. There was no iron overload and she did not need any special monitoring. Ultrasound abdomen showed cholelithiasis for which no active intervention was needed. There were no maternal high-risk conditions and she had a smooth antenatal period. She had vaginal delivery at term with average birth weight. Mother and baby were discharged without any morbidity. 
In this case, beta thalassemia major, homozygous for IVS 1-5 (G-C) mutation, showed features of thalassemia trait. A literature review showed a single case report by Bohara et al. [6] with similar presentation. Our case report is unique because the mutation is associated with pregnancy.

This extremely rare case report points to the fact that various modifiers can alter the severity of the mutation in the beta globin gene. HbF plays a major role in clinical presentation of beta thalassemia. Patients with high levels of $\mathrm{HbF}$ have less severe anemia [7]. Elevated levels of HbF modifies the balance between alpha and non-alpha globin chains and reduces the severity of beta thalassemia, both clinically and hematologically. The existence of $\mathrm{HbF}$ enhancer loci probably has changed the clinical picture in our case. Also various genetic interactions in the beta globin gene and outside the gene can affect the phenotypic presentation in beta thalassemia [8-11].

\section{Conclusions}

The study of such cases emphasizes the fact that genetic interactions are complex and regulation of $\mathrm{HbF}$ has a role in clinical manifestation of beta thalassemia major. Simultaneous inheritance of some loci that modulate $\mathrm{HbF}$ levels causes high level of total hemoglobin, thereby requiring no blood transfusion. Understanding the regulation of globin gene expression and gene-gene interactions may open up new avenues for management of patients with beta thalassemia major.

\section{Additional Information}

\section{Disclosures}

Human subjects: Consent was obtained or waived by all participants in this study. Conflicts of interest: In compliance with the ICMJE uniform disclosure form, all authors declare the following: Payment/services info: All authors have declared that no financial support was received from any organization for the submitted work. Financial relationships: All authors have declared that they have no financial relationships at present or within the previous three years with any organizations that might have an interest in the submitted work. Other relationships: All authors have declared that there are no other relationships or activities that could appear to have influenced the submitted work.

\section{References}

1. Leung TY, Lao TT: Thalassaemia in pregnancy. Best Pract Res Clin Obstet Gynaecol. 2012, 26:37-51. 10.1016/j.bpobgyn.2011.10.009

2. Sorrentino F, Maffei L, Caprari P, Cassetta R, Dell'Anna D, Materazzi S, Risoluti R: Pregnancy in thalassemia and sickle cell disease: the experience of an Italian thalassemia center. Front Mol Biosci. 2020, 7:16. 10.3389/fmolb.2020.00016

3. Cao A, Galanello R: Beta-thalassemia. Genet Med. 2010, 12:61-76. 10.1097/GIM.0b013e3181cd68ed

4. Petrakos G, Andriopoulos P, Tsironi M: Pregnancy in women with thalassemia: challenges and solutions . Int J Womens Health. 2016, 2016:441-51. 10.2147/IJWH.S89308

5. Fforde R: Management of beta thalassaemia in pregnancy. Obstet Gynaecol. 2014, 16:148-148. 10.1111/tog. 12100

6. Bohara V, Raut L, Badarkhe G, Roy SR, Chaudhuri U: Homozygosity for the severe $\beta(+)$-thalassemia mutation [IVS-I-5 $(\mathrm{G}>\mathrm{C})$ ] causes the phenotype of thalassemia trait: an extremely rare presentation. Hemoglobin. 2013, 37:101-5. 10.3109/03630269.2012.751395

7. Quek L, Thein SL: Molecular therapies in beta-thalassaemia . Br J Haematol. 2007, 136:353-65. 10.1111/j.1365-2141.2006.06408.x

8. Panigrahi I, Agarwal S: Genetic determinants of phenotype in beta-thalassemia . Hematology. 2008, 13:247252. 10.1179/102453308X316031

9. Taher AT, Weatherall DJ, Cappellini MD: Thalassaemia. Lancet. 2018, 13:155-167. 10.1016/S01406736(17)31822-6

10. Traivaree C, Monsereenusorn C, Rujkijyanont P, Prasertsin W, Boonyawat B: Genotype-phenotype correlation among beta-thalassemia and beta-thalassemia/HbE disease in Thai children: predictable clinical spectrum using genotypic analysis. J Blood Med. 2018, 2018:35-41. 10.2147/JBM.S159295

11. Cyrus C, Vatte C, Borgio JF, et al.: Existence of HbF enhancer haplotypes at HBS1L-MYB intergenic region in transfusion-dependent Saudi $\beta$-thalassemia Patients. Biomed Res Int. 2017, 2017:1972429. $10.1155 / 2017 / 1972429$ 